\title{
Oxide Bioceramic Composites in Orthopedics and Dentistry
}

\author{
Corrado Piconi * (D) and Simone Sprio (iD
}

check for

updates

Citation: Piconi, C.; Sprio, S. Oxide Bioceramic Composites in Orthopedics and Dentistry. J. Compos. Sci. 2021, 5, 206. https://doi.org/ $10.3390 /$ jcs5080206

Academic Editor: Francesco Tornabene

Received: 6 July 2021

Accepted: 30 July 2021

Published: 3 August 2021

Publisher's Note: MDPI stays neutral with regard to jurisdictional claims in published maps and institutional affiliations.

Copyright: (c) 2021 by the authors. Licensee MDPI, Basel, Switzerland. This article is an open access article distributed under the terms and conditions of the Creative Commons Attribution (CC BY) license (https:/ / creativecommons.org/licenses/by/ $4.0 /)$.
National Research Council of Italy, Institute of Science and Technology for Ceramics (CNR-ISTEC), 48018 Faenza, Italy; simone.sprio@istec.cnr.it

* Correspondence: corpico@libero.it

\begin{abstract}
Ceramic composites based on alumina and zirconia have found a wide field of application in the present century in orthopedic joint replacements, and their use in dentistry is spreading. The development of this class of bioceramic composites was started in the 1980s, but the first clinical applications of the total hip replacement joint were introduced in the market only in the early 2000s. Since then, several composite systems were introduced in joint replacements. These materials are classified as Zirconia-Toughened Alumina if alumina is the main component or as AluminaToughened Zirconia when zirconia is the main component. In addition, some of them may contain a third phase based on strontium exa-aluminate. The flexibility in device design due to the excellent mechanical behavior of this class of bioceramics results in a number of innovative devices for joint replacements in the hip, the knee, and the shoulder, as well in dental implants. This paper gives an overview of the different materials available and on orthopedic and dental devices made out of oxide bioceramic composites today on the market or under development.
\end{abstract}

Keywords: alumina; zirconia; Alumina-Toughened Zirconia; Zirconia-Toughened Alumina; hip arthroplasty; dental implants

\section{Introduction}

Oxides are among the most stable inorganic materials since no further oxidative processes (e.g., corrosion, ion release) can take place. This is a major reason for the use of oxides as ideal bioceramic materials since the 1960s because their chemical inertness was considered as the basis for biocompatibility. The first ceramic oxide used in orthopedics was alumina $\left(\mathrm{Al}_{2} \mathrm{O}_{3}\right)$, while ceramic composite oxides, prevalently made of alumina-zirconia $\left(\mathrm{Al}_{2} \mathrm{O}_{3}-\mathrm{ZrO}_{2}\right)$ were subsequently developed, seeking improved mechanical performance [1].

The first use of alumina as a biomaterial is due to Dr. Sami Sandhaus, a Swiss dentist, who in 1962 developed a screw-shaped dental implant named Crystalline Bone Screw$\mathrm{CBS}^{\circledR}$ and used it in a significant number of cases [2]. In 1963, L.W. Smith and J.F. Estes (Haeger Potteries, Dundee, IL, USA) developed Cerosium ${ }^{\mathrm{TM}}$ as a bone substitute in case of large bone defects, i.e., a silica aluminate matrix where pores (about $50 \%$ in volume) were filled with epoxy resin [3].

At that time, hip arthroplasty was taking its first steps. Although keenly interested by the potential of such a procedure, orthopedic surgeons were very concerned about the failures of implants due to the wear of bearings. The cooperation between Dr. Boutin-an orthopedic surgeon working in Pau, a town in Southern France-and one of his patients, the manager of a factory sited nearby manufacturing high alumina electric insulator, led to the first total hip replacement (THR) with an alumina-on-bearing in 1970 [4]. Such an implant had a stainless-steel stem and a Ultra-High Molecular Weight Polyethylene (UHMWPE) socket—soon replaced by a socket made of alumina-both cemented into bone.

In the same years, several scientists in Germany (i.e., G. Langer in Keramed, G. Heimke in Friedrichfeld, H. Dörre in Feldmüle, M. Saltzer in Rosenthal) gave a decisive contribution to the development of alumina for orthopedic components and overall for alumina as a 
biomaterial. This resulted in the development of a number of ceramic orthopedic devices, among which it is worthwhile to mention the BIOLOX ${ }^{\circledR}$ alumina developed by H. Dörre in Feldmüle (now CeramTec GmbH), which became "the ceramic" in orthopedics until this attribute was overtaken by the higher-performing BIOLOX ${ }^{\circledR}$ delta alumina-zirconia ceramic composite [5].

Indeed, alumina showed critical issues particularly related to failure of THR implants [6], leading some manufacturers to withdraw from the market of implantable ceramics. Alumina exhibits low fracture strength and toughness and is very sensitive to microstructural flaws that lead to a poor resistance to stress concentration or mechanical impact. As the presence of intergranular pores and large grain size are the main microstructural features that affect the mechanical strength of alumina, the efforts of ceramists were focused on decreasing the porosity and the grain size in alumina ceramics. This was obtained by the selection of proper precursors (e.g., alkoxide-derived powders) and by the optimization of the overall manufacturing process, from batch preparation to final densification by hot isostatic pressing (HIP). Such improvements resulted in the so-called "third generation alumina" based on high-purity precursors and characterized by finer grain size and density near the theoretical one, as illustrated in Table 1.

Table 1. Selected properties of alumina, evidencing the development of the material [5].

\begin{tabular}{ccccc}
\hline Property & Units & $\begin{array}{c}\text { First-Generation } \\
\text { Alumina } \\
\mathbf{( 1 9 7 0 s )}\end{array}$ & $\begin{array}{c}\text { Second-Generation } \\
\text { (BIOLOX }{ }^{\circledR}, \text { Since } \\
\text { 1974) }\end{array}$ & $\begin{array}{c}\text { Third-Generation } \\
\text { (BIOLOX }^{\circledR} \text { Forte } \\
\text { Since 1995) }\end{array}$ \\
\hline $\mathrm{Al}_{2} \mathrm{O}_{3}$ content & vol.\% & $99.1-99.6$ & 99.7 & $>99.8$ \\
\hline Density & $\mathrm{g} \mathrm{cm}^{-3}$ & $3.90-3.95$ & 3.95 & 3.97 \\
\hline Av. grain size & $\mu \mathrm{m}$ & $\leq 4.5$ & 4 & 1.75 \\
\hline Flexural strength & $\mathrm{MPa}$ & $>300$ & 400 & 630 \\
\hline Young's modulus & $\mathrm{GPa}$ & 380 & 410 & 407 \\
\hline Hardness & $\mathrm{HV}$ & 1800 & 1900 & 2000 \\
\hline
\end{tabular}

Nevertheless, the feasibility to obtain alumina components with specific design was limited by its typical brittle fracture behavior [7]. In response to these issues, the company Desmarquest (now Saint Gobain Céramiques Avancées Desmarquest-SGCAD, Evreux, France) followed a different approach: they focused their attention on a different, intrinsically tough ceramic, Yttria-stabilized Zirconia Polycrystal (Y-TZP). Zirconia (zirconium dioxide, $\mathrm{ZrO}_{2}$ ) is characterized by the polymorphism of its crystal lattice; therefore, it exists in three thermodynamically stable crystalline phases: monoclinic (up to $1170{ }^{\circ} \mathrm{C}$ ), tetragonal $\left(1170-2370^{\circ} \mathrm{C}\right)$, and cubic $\left(2370-2680^{\circ} \mathrm{C}\right)$. Effective applications of zirconia ceramics in medicine were made possible since the discovery of the stabilization of the tetragonal phase at room temperature based on the introduction of small amounts of oxide phases as stabilizers. Such a discovery led to the development of Partially Stabilized Zirconia (PSZ) [8] because the low concentration of the stabilizing oxide did not allow the full stabilization of the cubic phase. PSZ was firstly obtained by using calcium oxide as stabilizer, but successively either magnesium oxide (magnesia, $\mathrm{MgO}$ ) or yttrium oxide (yttria, $\mathrm{Y}_{2} \mathrm{O}_{3}$ ) were used for this purpose. The real breakthrough in the development of zirconia ceramics occurred in 1975 with the publication of the research paper "Ceramic Steel?" by Garvie, Hannink, and Pascoe [9]. They reported the increase in toughness in MgO-stabilized PSZ (Mg-PSZ) due to the transformation of the tetragonal phase into monoclinic. Such a transformation, taking place in a "martensitic" way as in some steels, results in an effective dissipative mechanism for fracture energy and, finally, in a self-toughening effect.

More recently, Gupta et al. [10] reported that a tetragonal zirconia ceramic showing grain size $\approx 0.3$ to $0.5 \mu \mathrm{m}$ could be obtained by using $2-3 \mathrm{~mol} \%$ of Yttrium Oxide (Yttria$\mathrm{Y}_{2} \mathrm{O}_{3}$ ) as a stabilizer, thus resulting in minimal residual cubic and monoclinic zirconia. Since then, although many studies had been dedicated to materials stabilized by $\mathrm{CaO}, \mathrm{MgO}$, 
and $\mathrm{CeO}$, the main zirconia ceramic that was developed industrially for the production of medical devices was the one stabilized by $\mathrm{Y}_{2} \mathrm{O}_{3}$. The tetragonal grains in Y-TZPbeing metastable - can shift to the monoclinic natural form at the expense of an external source of energy, i.e., the elastic stress field that yields an advancing crack. Thus, phase transformation results as an efficient dissipative mechanism for the energy that otherwise would lead to fracture. Indeed, it was evaluated that the tetragonal-monoclinic phase transformation implies (for a free grain) a volume expansion $4-5 \mathrm{vol} \%$. As each grain is constrained by its neighbors (the matrix), the constrained phase transformation generates a compressive stress field that increases the energy threshold that a crack has to overcome to develop further. These concurrent, energy-dissipative, microscopic-scale phenomena above outlined result, at a macroscopic level, in the remarkable bending strength and toughness of Y-TZP (see Table 2).

Table 2. Selected properties of Y-TZP. Alumina data reported for comparison.

\begin{tabular}{cccc}
\hline Property & Units & $\begin{array}{c}\text { Alumina } \\
\text { (1970s) }\end{array}$ & Y-TZP \\
\hline $\mathrm{Al}_{2} \mathrm{O}_{3}$ Content & vol $\%$ & $99.1-99.6$ & - \\
\hline $\mathrm{ZrO}_{2}$ Content & $\mathrm{vol} \%$ & - & $>99$ \\
\hline $\mathrm{Av}$. Grain Size $\mathrm{Al}_{2} \mathrm{O}_{3}$ & $\mu \mathrm{m}$ & $\leq 4.5$ & 0.3 \\
\hline Density & $\mathrm{g} / \mathrm{cm}^{3}$ & $3.90-3.95$ & 6.02 \\
\hline Thermal Conductivity & $\mathrm{W} / \mathrm{mK}$ & 30 & 2.5 \\
\hline Hardness & $\mathrm{HV}$ & 2000 & 1200 \\
\hline Flexural Strength & $\mathrm{MPa}$ & $>300$ & 1000 \\
\hline Fracture Toughness & $\mathrm{MPa} \mathrm{m} \frac{1}{2}$ & 3.5 & 4.5 \\
\hline Young Modulus & $\mathrm{GPa}$ & 380 & 210 \\
\hline
\end{tabular}

Several manufacturers worldwide started the production of Y-TZP ball heads. Among them, SGCAD—-the main manufacturer of zirconia (Y-TZP) ball heads worldwide-and Kyocera (Kyoto, Japan) developed also zirconia knee condylar components for total knee replacements (TKR).

The metastability of Y-TZP is the key for its outstanding mechanical performances. However, the metastability of Y-TZP was a cause of concern since the beginning of the clinical use of Y-TZP components. In the biologic environment, Y-TZP may spontaneously transform from tetragonal to monoclinic, drastically decreasing its mechanical properties [11]. Such an undesired phenomenon is named aging or low-temperature degradation (LTD). In THR bearings, the onset of LTD at the surface of the component is related to an increase of the surface roughness, in turn leading to the wear increase of UHMWPE acetabular cups that are usually coupled to Y-TZP heads [3]. The studies on the physicochemical mechanisms giving rise to LTD are still running: several models have been proposed to explain such a behavior, but none have been fully satisfactory to date [12], although it is acknowledged that LTD kinetics is promoted by temperature (especially for $\left.\mathrm{T}>100-150^{\circ} \mathrm{C}\right)$, by the presence of water in the environment, and by applied stresses. In addition, different LTD kinetics were observed in Y-TZP ball heads obtained from different manufacturers or from different batches produced by the same manufacturer, thus leaving open the main questions about the possible influence of the production process on LTD [13]. Finally, the unexpected high rates of failure in some batches of Y-TZP since 2000 [14] led to the abandon of its use in orthopedics.

\section{Biocompatibility of Alumina and Zirconia Composites}

The biological safety of alumina and zirconia and of alumina-zirconia composites has been established for a long time and was recently confirmed [15-18]. Tests on alumina, 
zirconia, and alumina-zirconia composites were performed using materials in the form of powders or dense ceramics, particularly addressing physicochemical features such as surface reactivity, chemical composition, impurity content, and type of stabilizer. The in vitro assays were performed using extracts in various media, in either direct or indirect contact, by using various cell lines such as macrophages, lymphocytes, fibroblasts, and osteoblasts. Similar considerations can be made on the in vivo tests, which had been performed in several implantation sites in different animal models, to analyze either adverse reactions in soft tissue and/or bone, as well as systemic toxicity. An absence of adverse reactions in cell culture either in tissues or organs after in vivo implants was observed whatever the culture conditions or the implants site.

\section{Alumina Zirconia Composites: Early Studies}

The abandon of zirconia in 2001 opened a technological gap, leaving unmet the urgent need of ceramic components for arthroplasty with effective design and increased reliability and longevity. Then, materials scientists turned their attention toward different zirconia-toughened ceramics (ZTCs), and promising results were obtained in the development of ceramic composites to be used as biomaterials in orthopedics. The work was focused on composites having alumina (in Zirconia-Toughened Alumina-ZTA) as the main component or zirconia (Alumina-Toughened Zirconia-ATZ).

Special attention was devoted to ZTAs. The basic concept of a ZTA material is to substantially increase the material fracture toughness and strength with respect to alumina, while maintaining relevant properties of alumina such as hardness, stiffness, and thermal conductivity, which are key factors for its successful clinical use in joint replacements. This is achieved by exploiting the tetragonal-to-monoclinic phase transformation of zirconia, which is introduced in ZTA as a reinforcing element. The key point for the excellent mechanical properties of ZTA ceramics is the transformability of the tetragonal zirconia. As a consequence, essential aspects are to retain a significant amount of the zirconia tetragonal phase at body temperature and its degree of stabilization in order to reach the desired toughening mechanism. The proper selection of the stabilizing oxide, the homogeneous and finely distribution of Y-TZP in the alumina matrix, and the control of the microstructure and grain size are key parameters to "tune" the stability of the tetragonal phase. In addition, the compressive residual stresses that develop on cooling, due to the mismatch in thermal expansion coefficients between the alumina matrix and the dispersed zirconia phase, increase the energy threshold for the T-M phase transformation, contributing to the strength of the composite [16].

This aspect is critical in the design of a ZTA composite: higher tetragonal zirconia stabilization as a consequence, for example, of a too high yttria concentration would lead to suppression of the zirconia phase transformation, then losing almost all the improvements of ZTA. On the other hand, poor zirconia stabilization-i.e., due to zirconia uncontrolled grain growth because of inappropriate sintering processes-would enhance the LTD of the material. Nevertheless, in the latter case, the mechanical properties might be outstanding, but the material could have unreliable performance, thus leading to catastrophic consequences due to the LTD of the zirconia phase.

Furthermore, it is perceived that the toughening mechanisms in monolithic Y-TZP and ZTA are significantly different. In monolithic zirconia, the stress induced by the single transformed ceramic grain makes the neighbor tetragonal zirconia transform as well, consequently spreading the transformation effect throughout the material. Such a transformation results in LTD and deterioration under long-term usage. In the case of alumina-zirconia composites, the zirconia phase is constrained in the stable alumina matrix, thereby preventing the transformation of the adjacent grains. Hence, the ZTA has a better retention of the tetragonal phase compared to the monolithic zirconia, when exposed to hydrothermal conditions in vitro [19].

The first studies on alumina-zirconia composites as biomaterials started during the mid-1980s by French researchers (INSA-Lyon, Ecole Centrale de Lyon) looking for a mate- 
rial strong and tough as zirconia but characterized by better resistance to LTD [20]. Among the tested material, a hot-pressed ZTA (Alumina-20 vol \% Y-TZP) showed bending strength (four-point bending) higher than $1100 \mathrm{MPa}$ and fracture toughness of about $10 \mathrm{MPa} \sqrt{ } \mathrm{m}$. Aging tests carried out using small bars implanted under the skin of Wistar rats-then in unloaded conditions -showed a limited decrease of the strength due to LTD. Laboratory wear tests (pin-on-disk, cylinder-on-flat) carried out against UHMWPE demonstrated an improved friction and wear behavior of hot-pressed ZTA in comparison with Y-TZP [21].

A further research project was carried out in the framework of the EUREKA programme (project EU 294) under the scientific coordination of the Italian Ceramic Centre (Bologna, Italy). The main goals attained were the production by slip casting of ZTA ball heads with several $\mathrm{Z} / \mathrm{A}$ ratios [22,23] and the assessment in a hip simulator of the wear behavior of ZTA-UHMWPE bearings. Wear tests were carried out in a hip simulator using Alumina-UHMWPE bearings as the reference. The results did not show significant differences between the experimental and reference material [24]. Cytotoxicity assays confirmed the absence of harmful effects elicited by the composite materials [25].

\section{Alumina-Zirconia Composites in Orthopedics Zirconia-Toughened Alumina}

The first ceramic composite introduced into the orthopedic market in 2002 was the alumina matrix composite (AMC) BIOLOX ${ }^{\circledR}$ delta, made by CeramTec $\mathrm{GmbH}$, Plochingen, Germany [26,27]. As reported by Burger [28], such a material was made of a fine-grained, high-purity alumina matrix (approximately $80 \mathrm{vol} \%$ ) combined with three different oxides, so as to retain the relevant properties typical of alumina such as stiffness, hardness, thermal conductivity, but improving fracture toughness and strength. To this aim, such an alumina matrix contained a tailored amount of zirconia phase (i.e., $\approx 17 \mathrm{vol} \%$ ), on the basis of indications provided by Pecharromán et al. [29], to obtain the best compromise between appropriate mechanical performance and chemical stability.

Previous works described the addition of strontium oxide ( $\mathrm{SrO}$ ) to the base formulation, with the purpose of activating solid-state reaction with alumina during sintering and triggering the in situ growth of elongated strontium hexa-aluminate $\left(\mathrm{SrAl}_{12} \mathrm{O}_{19}-\mathrm{SHA}\right)$ crystals with a magneto-plumbite structure. These platelet-shaped SHA grains, homogenously dispersed in the ceramic composite matrix, increased the toughness of the material through a mechanism of crack deflection/bridging. The effectiveness of this approach was demonstrated by Cutler et al. [30], who investigated a three-phase system formed by a 12 wt \% Ce-TZP matrix containing $\mathrm{Al}_{2} \mathrm{O}_{3}$ and SHA platelets nucleated in situ during sintering. The maximum platelets length is about $5 \mu \mathrm{m}$ with an aspect ratio of $5-10$. Figure 1 shows the microstructure of BIOLOX ${ }^{\circledR}$ delta, where the gray-colored grains represent the alumina matrix, while the white-colored grains represent the zirconia phase.

Then, two mechanisms are concurring to toughen and to reinforce such a composite: on one hand, the phase transformation of Y-TZP triggered by the tensile stresses in proximity of a crack tip is an effective energy-dissipative mechanism. On the other hand, the volume expansion associated to the T-M transformation is contrasted by the high stiffness of the alumina matrix, thus resulting in a compressive stresses field, which is highly effective in blocking the cracks propagation. Furthermore, the elongated zirconium aluminate crystals-formed upon solid-state reaction between alumina and zirconia during the sintering process - gave an additional contribution to the enhancement of the mechanical performance, acting indeed as short fibers capable of increasing the fracture strength and exerting an additional toughening effect. In addition to the reinforcing components, there are minor stabilizing oxides added to the material, giving additional effects such as specific coloring, such as the example of doping alumina with little chromium oxide amount $\left(\mathrm{Cr}_{2} \mathrm{O}_{3}\right)$, which gives the material its characteristic pink color. 


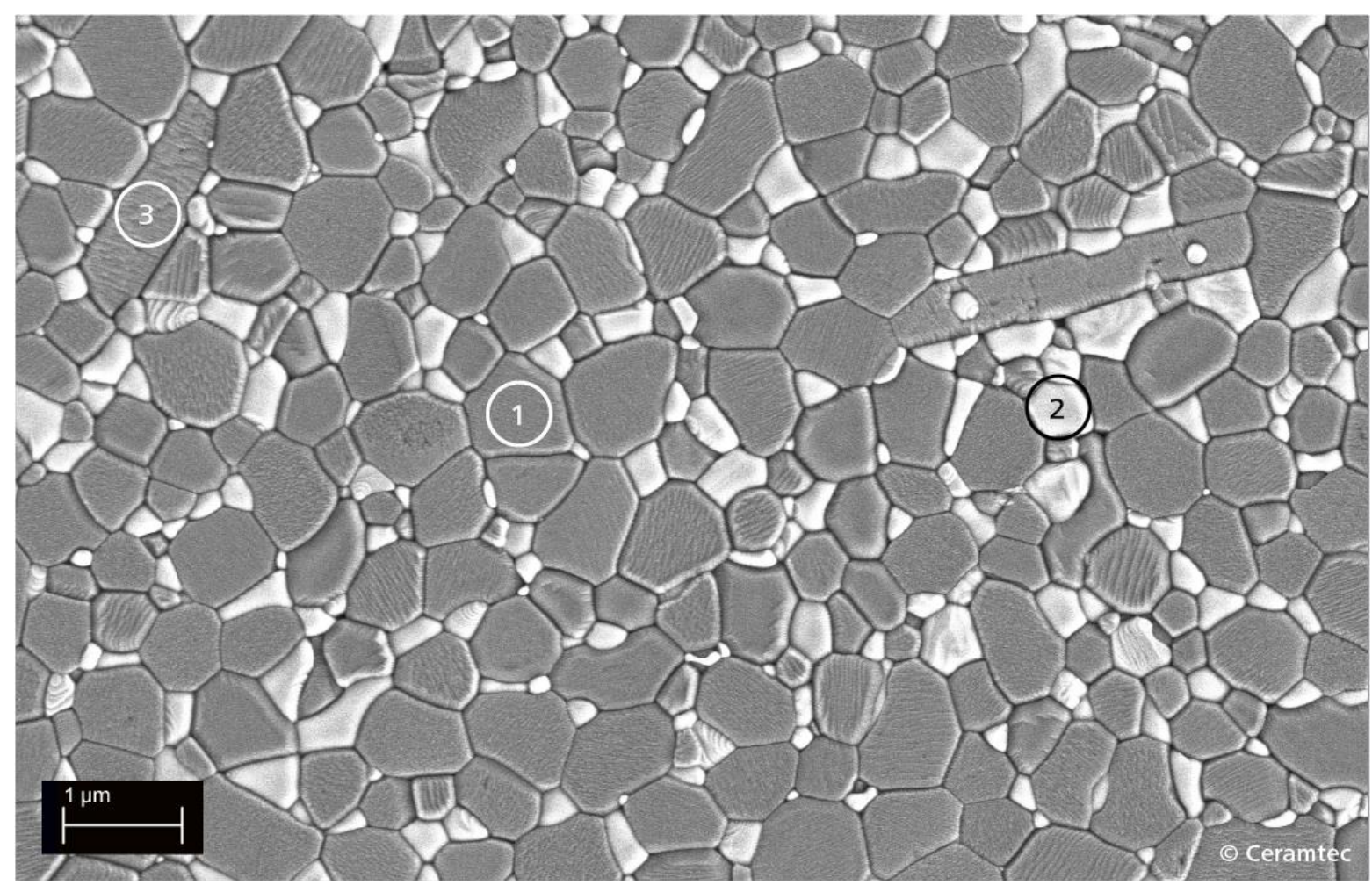

Figure 1. SEM image of the microstructure of the AMC composite ceramic BIOLOX ${ }^{\circledR}$ delta (Courtesy CeramTec GmbH, Plochingen, Germany). The gray grains (1) are the alumina matrix, the white grains (2) are the zirconia phase, and the elongated grains (3) consist of reinforcing strontium hexaaluminate (SHA) platelets.

CeramTec BIOLOX ${ }^{\circledR}$ delta is considered as the golden standard for ceramics in joint replacements bearings. BIOLOX ${ }^{\circledR}$ delta-which is characterized by a pink color, patented in the European market - is presently used for the production of ball heads that are manufactured in nine different diameters from 22 to $44 \mathrm{~mm}$ with four different neck lengths. The production of inserts is more differentiated, because it considers not only the inner but also the external design of the insert, to comply with the metallic shells of the different cup design now on the market.

A number of new ceramic devices were developed thanks to the behavior of AMC, as illustrated in Figure 2. This is including THR ball heads expressly designed for use during revision surgeries, ceramic components for knee replacements, humeral heads for shoulder replacements, and ceramic hip resurfacing implants [31].
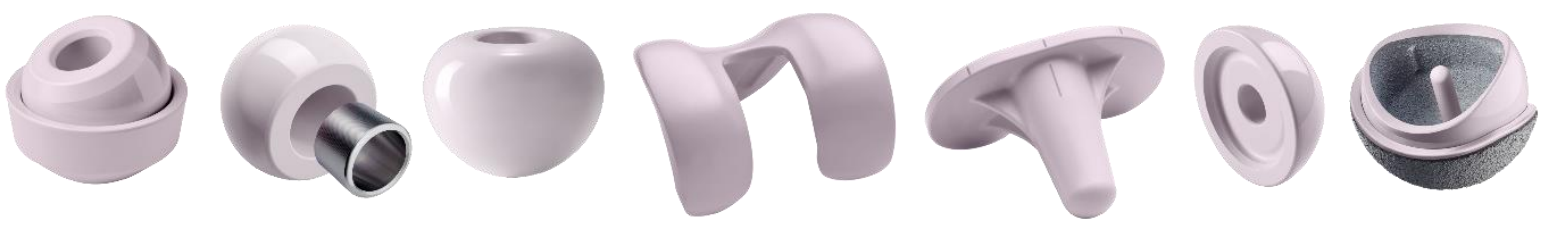

Figure 2. AMC BIOLOX ${ }^{\circledR}$ delta products (Courtesy CeramTec GmbH, Plochingen, Germany).

Kyocera Medical Corp (Kyoto, Japan—formerly Japan Medical Materials) followed an original approach. The company is a historical manufacturer of fine ceramics for biomedical applications, the first implants of its alumina Bioceram ${ }^{\circledR}$ may be traced back to 1976. In 2010, Kyocera developed a ZTA (BioCeram ${ }^{\circledR}$ AZ209) where zirconia is stabilized in the tetragonal state by residual stresses only [32]. This is obtained by fine tuning of the grain size during cooling. 
A more complex composite was released to the market in 2015 under the trademark of Bioceram ${ }^{\circledR}$ AZUL, which was likely chosen for its characteristic blue color [33,34]. AZUL contains approximately $19 \mathrm{wt} \%$ zirconia and $2 \mathrm{wt} \%$ oxide additives mixed with highpurity fine alumina. The addition of a mixture of oxides characterized by platelet-like grains, such as $\mathrm{TiO}_{2}, \mathrm{MgO}, \mathrm{Co}_{3} \mathrm{O}_{4}, \mathrm{SiO}_{2}$, and $\mathrm{SrO}$, aimed to reduce the grain size and induce the precipitation of platelet-like SHA grains. Additives used in the ZTA synthesis, except for silicon, were located in that platelet-like grain, substituting for strontium and/or aluminum [35]. Stress relaxation due to the zirconia particles and the crack-diverting effect of $\mathrm{S} 6 \mathrm{H}$ crystals are relevant factors promoting the high strength and toughness of Bioceram ${ }^{\circledR}$ AZUL.

A further ZTA (25 vol \% Y-TZP, alumina balance) was introduced on the orthopedic market under the trade name Symarec ${ }^{\circledR}$ on 2015 by Mathys Orthopedie (Bettlach, Switzerland), who incorporated the company Keramed (formerly Keramik Werk HermsdorfKWK Moesdorf, Germany). Keramed is among the pioneers in bioceramics, manufacturing

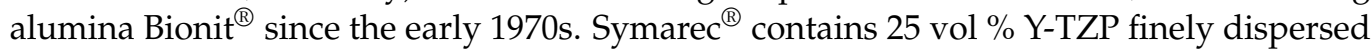
in the alumina matrix (75 vol \%) [36].

\section{Alumina-Toughened Zirconia}

Similarly to the ZTA, the ATZ aimed to combine the advantages of the two monolithic materials. Although ATZ may appear of relatively simple design, the properties of these special materials depend significantly on the production steps and conditions, as already previously pointed out.

So far, Mathys Orthopedie (Bettlach, Switzerland) introduced the only ATZ for orthopedic applications in the market in 2007 under the trade name Ceramys ${ }^{\circledR}$ [37]. The mechanical behavior of the material is remarkable and, in some cases, it produced better results than the ZTA alternatives (see Table 3).

Table 3. Selected properties of alumina-zirconia composites for orthopedic applications. Adapted from [31]. (n.s.: not specified; *: measured by ring-on-ring bending).

\begin{tabular}{cccccccc}
\hline \multirow{2}{*}{ Property } & Units & \multicolumn{2}{c}{ CeramTec GmbH } & \multicolumn{2}{c}{ Mathys AG } & \multicolumn{2}{c}{ Kyocera Medical } \\
\cline { 3 - 8 } & & $\begin{array}{c}\text { Alumina } \\
\text { BIOLOX forte }\end{array}$ & $\begin{array}{c}\text { BIOLOX } \\
\text { Delta }\end{array}$ & Symarec ZTA & $\begin{array}{c}\text { Ceramys } \\
\text { ATZ }\end{array}$ & AZ209 & AZUL \\
\hline $\mathrm{Al}_{2} \mathrm{O}_{3}$ Content & $\mathrm{vol} \%$ & $>99.8$ & 79 & 75 & 20 & 84 & 79 \\
\hline $\mathrm{ZrO}_{2}$ Content & $\mathrm{vol} \%$ & - & 17 & 25 & 80 & 14 & 19 \\
\hline Other Oxides & $\mathrm{Vol} \%$ & - & 1 & n.s. & n.s & 2 & 2 \\
\hline Density & $\mathrm{g} / \mathrm{cm}^{3}$ & 3.97 & 4.37 & 4.37 & 5.51 & 4.35 & n.s. \\
\hline Av. Grain Size $\mathrm{Al}_{2} \mathrm{O}_{3}$ & $\mu \mathrm{m}$ & 1.75 & 0.56 & 0.8 & 0.4 & 0.35 & 0.3 \\
\hline Vickers Hardness & $\mathrm{GPa}$ & 20 & 19 & $20(\mathrm{HV} 1)$ & $15(\mathrm{HV} 20)$ & 17 & 17.4 \\
\hline Flexural Strength (4-Point Bend) & $\mathrm{MPa}$ & 631 & 1384 & $\geq 700\left(^{*}\right)$ & $\geq 900\left(^{*}\right)$ & 1200 & 1399 \\
\hline Fracture Toughness & $\mathrm{MPa} \mathrm{m}{ }^{\frac{1}{2}}$ & 4.5 & 6.5 & $\geq 5$ & $\geq 7$ & 4.3 & 4.5 \\
\hline
\end{tabular}

Ceramys ${ }^{\circledR}$ is presently the oxide ceramic composite with the higher toughness now on the market. The production of ball heads covers the most significant diameters now in clinical use $(29,32,36 \mathrm{~mm})$. Mathys is manufacturing also sleeved ball heads using the ATZ Ceramys ${ }^{\circledR}$, for use in revision surgery or in primary implants thanks to extra-long sleeves.

The Ceramys ${ }^{\circledR}$ is sometimes described as a composite made of $80 \mathrm{wt} \%$ zirconia and $20 \mathrm{wt} \%$ alumina. More in detail, Schneider, et al. [38] describe the Ceramys ${ }^{\circledR}$ as formed by $61 \%$ tetragonal zirconia, $17 \%$ cubic zirconia, approximately $1 \%$ monoclinic zirconia, and alpha-alumina. The tetragonal zirconia phase is stabilized with $3 \mathrm{~mol} \% \mathrm{yttria}$ as for the standard monolithic zirconia (3Y-TZP). The alumina grains are finely dispersed in the zirconia matrix, and the average grain size approaches $0.4 \mu \mathrm{m}$, both for $\mathrm{ZrO}_{2}$ and $\mathrm{Al}_{2} \mathrm{O}_{3}$. 
According to Oberbach et al. [39] the biaxial flexural strength (acc. to standard ISO 6474) surpassed $1200 \mathrm{MPa}$. The pin-on-disk wear test with ATZ/ATZ couplings using serum as a fluid test medium was shown to be comparable to $\mathrm{Al}_{2} \mathrm{O}_{3} / \mathrm{Al}_{2} \mathrm{O}_{3}$ couplings (i.e., $0.152 \mathrm{~mm}^{3}$ and $0.157 \mathrm{~mm}^{3}$ of weight loss, for $\mathrm{ATZ}$ and $\mathrm{Al}_{2} \mathrm{O}_{3}$, respectively) [40].

Some properties of currently manufactured alumina-zirconia ceramic composites for orthopedic applications are summarized in Table 3.

The interest for zirconia-toughened ceramics (ZTCs) in dentistry is mainly due to the present evolution in the device design. Namely, metal-free dental implants are becoming more and more demanded by patients, and in the last 20 years, Y-TZP is used to produce crowns and bridges as a structural ceramic as well as in dental implants [41].

Several alumina-zirconia ceramic composites are already in use in dentistry. The one with the longer clinical record is known under the trade name NANOZR ${ }^{\circledR}$ (Matsushita/Panasonic, Osaka, Japan). Developed by Nawa et al. in the late 1990s, it is an ATZ composite ceramic constituted of $10 \mathrm{~mol} \% \mathrm{Ce}$-TZP matrix with $30 \mathrm{vol} \% \mathrm{Al}_{2} \mathrm{O}_{3}$ [42,43]. This material shows an intergranular type nanostructure, in which several $10-100 \mathrm{~nm}$ $\mathrm{Al}_{2} \mathrm{O}_{3}$ particles are trapped within the $\mathrm{ZrO}_{2}$ grains and several $10 \mathrm{~nm} \mathrm{ZrO}_{2}$ particles are trapped within the $\mathrm{Al}_{2} \mathrm{O}_{3}$ grains. NANOZR ${ }^{\circledR}$ is now in use in CAD/CAM milling blanks for dental restorations (crown, bridges, etc.), and tests are now in progress in the view of its use in dental implants [44].

Dental implants made of Y-TZP are rather common today, and the large majority of the devices on the market are single-piece devices. As an alternative, a growing number of manufacturers are proposing two-piece dental implants made of Y-TZP. The design of the connection in two-piece implants is a challenging issue because of the small overall diameter of the device (3.5-4 mm) and the reduction in thickness of the walls in the zone of connection. The reliability of these devices can be improved by the use of composites. In addition, alumina-zirconia ceramic composites are expected to increase the reliability of small diameter implants (e.g., 3.5-3.25 mm in diameter) that are the most critical from the mechanical viewpoint.

The ATZ now in clinical use for dental implants is BioHip ${ }^{\circledR}$ (Metoxit, Tahingen, Switzerland) [45]. This material is a fine and homogeneous dispersion of $\mathrm{Al}_{2} \mathrm{O}_{3}$ grains $(\mathrm{D} \approx 0.4 \mu \mathrm{m})$ in a submicron-size $\mathrm{Y}$-TZP matrix, and it shows a marked improvement in the mechanical behavior with respect to Y-TZP (see Table 3). Zeralock and Zeramex Plus dental implants too (Dentalpoint, Zurich, Switzerland) are made out of ATZ BioHip ${ }^{\circledR}$. The retrospective analysis of the company database demonstrates the excellent success rate of these two systems, $98.5 \%$ at $>2$ years follow up (Zeralock) and $99.4 \%$ at $>1$ year follow up (Zeramex Plus) [46].

\section{Developments in Progress}

The developments in progress in alumina-zirconia ceramic composite as biomaterials are presently based on the development of new medical devices using materials already established. This is true especially for applications in dental implants fostered by manufacturers developing two-piece and small diameter $(<4 \mathrm{~mm})$ dental implants. In addition, the present regulatory framework is making it difficult to introduce new materials in dental implants due to their class of risk (IIb).

As an illustrative example of this situation, it is noted that the small diameter implants now under development (2021) are based on a Ce-TZP-based triphasic composite already described six years ago $[47,48]$. Ceramic composites replacing Y-TZP by Ce-TZP are being studied for application in dentistry, i.e., by Apel et al. [49], who reported the processing of a ceria-doped tetragonal zirconia polycrystal-based composite (10Ce-TZP/16 vol \% $\mathrm{MgAl}_{2} \mathrm{O}_{4}$ ), obtained by slip casting and die pressing of commercially available powders. Their work shows that the material is enhanced by the inter- or intra-granular dispersion of nano-scaled (max $200 \mathrm{~nm}$ ) magnesia spinel, mostly at the grain boundaries of the Ce-TZP matrix but also within the zirconia grains. Moreover, this material contains very fine 
zirconia crystals within the spinel grains. Negligible LTD was observed after aging at $134{ }^{\circ} \mathrm{C}$ in saturated steam for $450 \mathrm{~h} \mathrm{[49].}$

Ce-TZP $/ \mathrm{Al}_{2} \mathrm{O}_{3}$ composites were extensively studied in the framework of two EUfunded research projects, named LONGLIFE and SISCERA. The Ce-TZP/8 vol \% $\mathrm{Al}_{2} \mathrm{O}_{3} / 8$ vol \% SHA composites (referred to as ZA8Sr8) were recently developed using as a precursor a powder obtained by the surface-coating route [50]. Reveron et al. reported that using coated powders allows homogeneous distribution of the second phases in the zirconia matrix, the tailoring of grain size and morphology, and a close control of the stoichiometry [51]. The mechanical properties of the triphasic composite ZA8Sr8 are summarized in Table 4. In addition, ZA8Sr8 shows optimum LTD resistance; the monoclinic fraction after $50 \mathrm{~h}$ of hydrothermal treatment $\left(134^{\circ} \mathrm{C}\right.$, sat. steam) is about $10 \mathrm{vol} \%$ in comparison with $70 \mathrm{vol} \%$ in Y-TZP treated in the same conditions [52].

Table 4. Selected characteristics of some ZTC of interest as materials for dental implants. Flexural strength measured on 4-p bending bars. * Biaxial measure on discs following ISO 6872.

\begin{tabular}{|c|c|c|c|c|c|c|}
\hline \multicolumn{2}{|c|}{ Material } & \multirow{2}{*}{$\begin{array}{c}\text { Ref } \\
16\end{array}$} & \multirow{2}{*}{$\begin{array}{c}\text { Composition } \\
\mathrm{ZrO}_{2} / 3 \mathrm{~mol} \% \mathrm{Y}_{2} \mathrm{O}_{3}\end{array}$} & \multirow{2}{*}{$\begin{array}{c}\begin{array}{c}\text { Flexural } \\
\text { Strength (MPa) }\end{array} \\
900-1200 \\
\end{array}$} & \multirow{2}{*}{$\begin{array}{c}\begin{array}{c}\text { Toughness } \\
(\mathbf{M P a} \cdot \sqrt{ } \mathbf{m})\end{array} \\
6-10 \\
\end{array}$} & \multirow{2}{*}{$\begin{array}{c}\text { Hardness(GPa) } \\
12-14 \\
\end{array}$} \\
\hline Reference & Y-TZP & & & & & \\
\hline \multirow{2}{*}{ Commercial } & NANOZR $^{\circledR}$ & 42 & $\begin{array}{c}10 \mathrm{~mol} \% \mathrm{Ce}-\mathrm{TZP} / 30 \\
\text { vol. } \% \mathrm{Al}_{2} \mathrm{O}_{3}\end{array}$ & $1290\left({ }^{*}\right)$ & 8.6 & 11.5 \\
\hline & $\begin{array}{c}\text { ATZ } \\
\text { BioHip }^{\circledR}\end{array}$ & 38 & $\mathrm{Y}-\mathrm{TZP} / 20 \mathrm{vol} \% \mathrm{Al}_{2} \mathrm{O}_{3}$ & 1400 & 8 & 14 \\
\hline \multirow{3}{*}{ Under development } & ZCA5P & 54 & $\begin{array}{c}\text { Y-Ce- } \\
\mathrm{TZP} / \mathrm{Al}_{2} \mathrm{O}_{3} / \mathrm{LaAl}_{11} \mathrm{O}_{18}\end{array}$ & 1250 & 8,5 & 13.5 \\
\hline & ZA8Sr8 & 51 & $\begin{array}{c}8 \text { vol \%Al2O3/8 vol \% } \\
\text { SHA/Ce-TZP }\end{array}$ & $1197\left(^{*}\right)$ & 10.2 & - \\
\hline & HTZ500 & 55 & $\begin{array}{c}\mathrm{ZrO}_{2} / 2 \mathrm{~mol} \% \mathrm{Y}_{2} \mathrm{O}_{3} / 5 \\
\text { vol \% SHA }\end{array}$ & 1628 & 8.6 & 12.6 \\
\hline
\end{tabular}

A further approach to increase the strength and toughness of ceramics is based on the introduction of elongated phases that increase the toughness of the material by crack deflection/bridging as discussed previously in the case of SHA platelets in an alumina matrix. Similar platelet-like grains made out of lanthanum hexaluminate $\left(\mathrm{LaAl}_{11} \mathrm{O}_{18}\right.$ LHA) nucleated in Ce-TZP during sintering were reported by Miura et al. [53].

Similar structures reinforced by LHA can be obtained in a Y-TZP matrix, leading to materials with variable behavior depending on the volume fractions of the different phases, i.e., the ZCA10P composite (Oximatec $\mathrm{GmbH}$, Hochsdorf, Germany) containing $10 \mathrm{vol} \%$ platelets described by Burger [54], illustrated in Figure 3.

Further materials that are expected to originate innovative devices in dental implantology are the ones described by Gottwik et al. [55]. They disclosed a new material with remarkable mechanical behavior. Identified as HTZ500, it consists of a matrix of $2 \mathrm{~mol} \%$ Y-TZP (grain size: $0.27 \mu \mathrm{m}$ ) containing a dispersion of $5 \mathrm{vol} \%$ SHA platelets [55]. The bending strength is $\approx 1.6$ times the Y-TZP one. This material is especially of interest for its strength after scratching or after indentation, which is defined by the author as "damage tolerance" [56]. Namely, the abutment of one-piece dental implants is finished by grinding, which may originate a network of subsurface cracks that may grow until fracture, which is driven by the stresses applied during clinical use [57].

Other approaches to increase the mechanical behavior of ZTA were followed by Duntu et al. [58]. They observed a relevant increase in hardness and toughness after the addition of graphene to the material. In hot pressed ceramics, fracture toughness was increased up to $115 \%$, while the fracture toughness (KIC) of alumina- $10 \mathrm{wt} \% \mathrm{ZrO}_{2}$-was increased up to $164 \%$ thanks to the refinement in grain size of the alumina matrix and to the toughening effects of intergranular graphene and $\mathrm{ZrO}_{2}$ grains. 


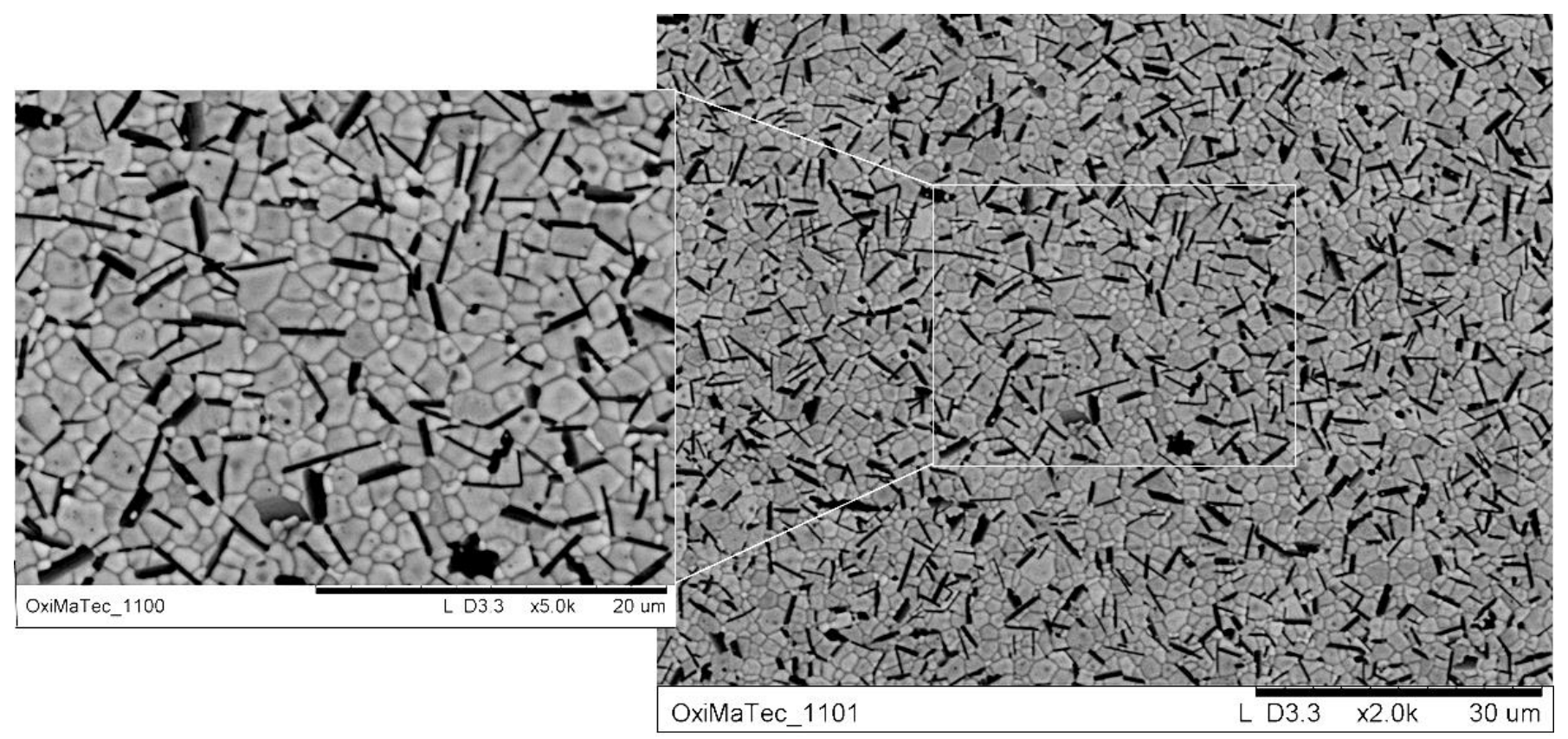

Figure 3. Microstructure of Ce-TZP/ $\mathrm{LaAl}_{11} \mathrm{O}_{18}$ composite (ZCA10P) (courtesy Dr. W. Burger, Oxymatec Gmbh, Hochdorf, Germany).

A further approach to improve the mechanical behavior of ZTA consists in adding $\mathrm{TiO}_{2}$ to the composite, thus increasing the composite density $[59,60]$.

Khaskhoussi et al. [61] reported the results of the biological characterization in vitro of experimental ternary alumina/ $12 \mathrm{~mol} \%$ ceria-stabilized zirconia/titania ceramic composites. Adding $\mathrm{TiO}_{2}$ in ZTA is known as an effective way to increase alumina and zirconia density [60]. The tests demonstrated that these composites may be able to promote cell adhesion and bonding in the tissue and implant interface, but these promising results must be confirmed in vivo. In addition, genotoxic effects were observed in the composites with higher concentration of $\mathrm{TiO}_{2}$ tested $(10 \mathrm{wt} \%)$, indicating the need to establish a threshold for this component in the ceramic.

\section{Conclusions}

Alumina-zirconia ceramic composites have wide acceptance in orthopedics, and their relevance is growing in dentistry. This due to the biological safety of the materials now in production, their stability, and their outstanding mechanical properties.

In orthopedics, the large majority of orthopedic companies rely on BIOLOX ${ }^{\circledR}$ delta for ceramic components for THR bearings. This ceramic covers more than $90 \%$ of the worldwide market, while the ones made by competitors rely on niche markets only. More than 5 million patients so far are taking advantage of ceramic components made out of this material.

BIOLOX ${ }^{\circledR}$ delta is today "the ceramic" in hip replacement bearings worldwide, and it is becoming the material of choice for ceramic bearings in the growing field of shoulder arthroplasty. Attempts to use ZTA components in knee arthroplasty are limited to niche markets mainly due to the high pricing of bioceramic knee replacements because of their design, which is much more complex that the spherical joint of the hip or of the glenoid component for shoulder replacements.

In dentistry, especially in implantology, ceramic devices had to cope with the clinical success of titanium implants. Although ceramic dental implants have had a clinical outcome analogous to the titanium ones, the share of ceramic implants-although steadily growing-is today no more than $10 \%$ of the market. 
The diffusion of ceramic implant in dentistry is depending on the formation of practitioners, who could hence add these devices to the array of solutions that they propose to their patients.

The standard material for ceramic dental implants is Y-TZP, but some implant manufacturers already use ATZ. The growing interest for two-piece implants and for small diameter may widen the application of oxide ceramic composites, especially the ternary ones making use of ceria-stabilized zirconia and SHA platelets, because of their mechanical properties.

Although several experimental materials are under study, their future appears uncertain due to the strict rules of the regulatory systems for medical devices that are making the approval of new materials more and more difficult.

We note the growing attention on ceramic implants by the global players of the dental market, which will lead to significant changes in the dental implantology field during the next few years. The major companies recently made agreements with, or acquisition of, companies involved in material development and/or in the manufacture of ceramic dental implants. A new momentum to metal-free implantology and to oxide ceramic composites biomaterials in this field can be expected from these operations.

Author Contributions: writing—original draft preparation, P.C.; writing—review and editing, S.S. All authors have read and agreed to the published version of the manuscript.

Funding: This research received no external funding.

Conflicts of Interest: The authors declare no conflict of interest.

\begin{tabular}{ll}
\multicolumn{2}{l}{ Abbreviations } \\
AMC & Alumina Matrix Composite \\
ATZ & Alumina-Toughened Zirconia \\
HIP & Hot Isostatic Pressing \\
LTD & Low-Temperature Degradation \\
SHA & Strontium Exaluminate \\
TKR & Total Knee Replacement \\
THR & Total Hip Replacement \\
UHMWPE & Ultra-High Molecular Weight Polyethylene \\
Y-TZP & Yttria-stabilized Tetragonal Zirconia Polycrystal \\
ZTA & Zirconia-Toughened Alumina \\
ZTC & Zirconia-Toughened Ceramics
\end{tabular}

\section{References}

1. Piconi, C.; Maccauro, G.; Muratori, E.; del Brach Prever, E. Alumina and zirconia ceramics in joint replacements: A review. J. Appl. Biomat. Biomech. 2003, 1, 19-32.

2. Sandhaus, S. Noveaux Aspects de l'Implantologie. L'Implant CBS; Gessler SA: Sion, Switzerland, 1969.

3. Smith, L. Ceramic-Plastic Material as a Bone Substitute. Arch. Surg. 1963, 87, 653-661. [CrossRef]

4. Boutin, P. Arthroplastie totale de la hanche par prosthéses en alumine fritté. Rev. Chir. Orthop. 1972, 58, 230-246.

5. Piconi, C. Alumina. In Comprehensive Biomaterials II; Ducheyne, P., Grainger, D.W., Healy, K.E., Hutmacher, D.W., Kirkpatrick, C.J., Eds.; Elsevier: Oxford, UK, 2017; Volume 1, pp. 92-121.

6. Piconi, C.; Labanti, M.; Magnani, G.; Caporale, M.; Maccauro, G.; Magliocchetti, G. Analysis of a failed alumina THR ball head. Biomaterials 1999, 20, 1637-1646. [CrossRef]

7. Traina, F.; De Fine, M.; Di Martino, A.; Faldini, C. Fracture of Ceramic Bearing Surfaces following Total Hip Replacement: A Systematic Review. BioMed Res. Int. 2013, 2013, 1-8. [CrossRef]

8. Garvie, R.C.; Nicholson, P.S. Structure and thermodynamical properties of Partially Stabilized Zirconia in the $\mathrm{CaO}^{-} \mathrm{ZrO}_{2}$ System. J. Am. Ceram. Soc. 1972, 55, 152-157. [CrossRef]

9. Garvie, R.C.; Hannink, R.H.J.; Pascoe, R.T. Ceramic Steel? Nature 1975, 258, 703-704. [CrossRef]

10. Gupta, T.K.; Bechtold, J.H.; Kuznicki, R.C.; Cadoff, L.H.; Rossing, B.R. Stabilization of tetragonal phase in polycrystalline zirconia. J. Mater. Sci. 1977, 12, 2421-2426. [CrossRef]

11. Piconi, C.; Maccauro, G. Zirconia as a ceramic biomaterial. Biomaterials 1999, 20, 1-25. [CrossRef]

12. Lughi, V.; Sergo, V. Low temperature degradation -aging- of zirconia: A critical review of the relevant aspects in dentistry. Dent. Mater. 2010, 26, 807-820. [CrossRef] 
13. Piconi, C.; Maccauro, G.; Angeloni, M.; Rossi, B.; Learmonh, I.D. Zirconia heads in perspective: A survey of zirconia outcomes in total hip replacements. Hip. Intl. 2007, 17, 119-130. [CrossRef]

14. Piconi, C.; Maccauro, G.; Pilloni, L.; Burger, W.; Muratori, F.; Richter, H.G. On the fracture of a zirconia ball head. J. Mater. Sci. Mater. Med. 2006, 17, 289-300. [CrossRef]

15. Kretzer, J.P.; Mueller, U.; Streit, M.R.; Kiefer, H.; Sonntag, R.; Streicher, R.M.; Reinders, J. Ion release in ceramic bearings for total hip replacement: Results from an in vitro and an in vivo study. Int.Orthop. 2018, 42, 65-70. [CrossRef]

16. Piconi, C.; Porporati, A. Bioinert ceramics: Zirconia and alumina. In Handbook of Bioceramics and Biocomposites; Antoniac, I., Ed.; Springer: Berlin, Germany, 2016; Volume 1, pp. 59-90.

17. Alasvand, N.; Banijamali, S.; Milan, P.B.; Mozafari, M. Cellular response to alumina. In Handbook of Biomaterials Biocompatibility; Elsevier BV: Amsterdam, The Netherlands, 2020; pp. 335-352.

18. Manicone, P.F.; Ziranu, A.; Perna, A.; Maccauro, G. Cellular response to zirconia. In Handbook of Biomaterials Biocompatibility; Mozafari, M., Ed.; Woodhead: Cambridge, UK, 2020; pp. 335-352.

19. Fabbri, P.; Piconi, C.; Burresi, E.; Magnani, G.; Mazzanti, F.; Mingazzini, C. Lifetime estimation of a zirconia-alumina composite for biomedical applications. Dent. Mater. 2014, 30, 138-142. [CrossRef]

20. Mandrino, A.; Moyen, B.; Ben Abdallah, A.; Treheux, D.; Orange, D. Aluminas with dispersoids. Tribol. Prop. In Vivo Aging. Biomater. 1990, 11, 88-91.

21. Ben Abdallah, A.; Treheux, D. Frictional and wear of ultrahigh molecular weight polyethylene against various new ceramics. Wear 1991, 142, 43-56. [CrossRef]

22. Agathopoulos, S.; Nikolopoulos, P.; Salomoni, A.; Tucci, A.; Stamenkovich, I. Preparation and properties of binary oxide bioceramics. J. Mater. Sci. Mater. Med. 1996, 7, 629-636. [CrossRef]

23. Salomoni, A.; Tucci, A.; Esposito, L.; Stamenkovich, I. Forming and sintering of multiphase bioceramics. J. Mater. Sci. Mater. Med. 1994, 5, 651-653. [CrossRef]

24. Affatato, S.; Testoni, M.; Cacciari, G.L.; Toni, A. Mixed-oxide prosthetic ceramic ball heads. Part 1: Effect of the ZrO2 fraction on the wear of ceramic on polyethylene joints. Biomaterials 1999, 20, 971-975. [CrossRef]

25. Ciapetti, G.; Verri, E.; Savioli, F.; Pizzoferrato, A. Vitro Cytotoxicity Testing of Bioceramics for Hip Prosthesis. Proc. 9th SIMCER; Palmonari, C., Stamenkovic, I., Eds.; Centro Ceramico: Bologna, Italy, 2000; pp. 39-42.

26. Burger, W.; Richter, H.G. High strength and toughness alumina matrix composites by transformation toughening and "in situ" platelet reinforcement (ZPTA). Key Eng. Mater. 2001, 192-195, 545-548.

27. Heimke, G.; Leyen, S.; Willmann, G. Knee arthoplasty: Recently developed ceramics offer new solutions. Biomaterials 2002, 23, 1539-1551. [CrossRef]

28. Burger, W. Oxidkeramik wieder im Trend-neue Werkstoffe für die Medizintechnik und industrielle Anwendungen. Keram. Z. 2012, 2, 134-137.

29. Pecharromán, C.; Bartolome, J.F.; Requena, J.; Moya, J.; Deville, S.; Chevalier, J.; Fantozzi, G.; Torrecillas, R. Percolative Mechanism of Aging in Zirconia-Containing Ceramics for Medical Applications. Adv. Mater. 2003, 15, 507-511. [CrossRef]

30. Cutler, R.A.; Lindemann, J.M.; Ulvensøen, J.H.; Lange, H.I. Damage-resistant SrO doped Ce-TZP/Al2O3 composites. Mater. Des. 1994, 15, 123-133. [CrossRef]

31. Piconi, C. Ceramics for joint replacement: Design and application of commercial bearings. In Advances in Ceramic Biomaterials; Palmero, P., Cambier, F., De Barra, E., Eds.; Woodhead: Duxford, UK, 2017; pp. 129-179.

32. Ikeda, J.; Mabuchi, M.; Nakanishi, T.; Miyaji, F.; Ueno, M.; Pezzotti, G. Phase Stability and Fracture Toughness of Zirconia Toughened Alumina for Joint Replacement. Damage Assess. Struct. VII 2007, 361, 767-770. [CrossRef]

33. Ikeda, J.; Murakami, T.; Shimozono, T.; Watanabe, R.; Iwamoto, M.; Nakanishi, T. Characteristics of Low Temperature Degradation Free ZTA for Artificial Joint. Key Eng. Mater. 2014, 631, 18-22. [CrossRef]

34. Available online: https://global.kyocera.com/prdct/medical/technology/bioceram/material.html (accessed on $30 \mathrm{June} 2021$ ).

35. Ikeda, J.; Murakami, T.; Sasaki, T.; Shimozono, T.; Shouyama, Y.; Iwamoto, M. Wear amd corrosion resistance of low temperature degradation free ZTA for artificial joints. Key Eng. Mater. 2017, 720, 296-300. [CrossRef]

36. Al-Hajjar, M.; Jennings, L.M.; Begand, S.; Oberbach, T.; Delfosse, D.; Fisher, J. Wear of novel ceramic-on-ceramic bearings under adverse and clinically relevant hip simulator conditions. J. Biomed. Mater. Res. Part B Appl. Biomater. 2013, 101, $1456-1462$. [CrossRef]

37. Begand, S.; Glien, W.; Oberbach, T. ATZ-A New Material with a High Potential in Joint Replacement. Key Eng. Mater. 2005, 284-286, 983-986. [CrossRef]

38. Schneider, J.; Begand, S.; Kriegel, R.; Kaps, C.; Glien, W.; Oberbach, T. Low Temperature aging of Alumina Toughened Zirconia. J. Am. Ceram. Soc. 2008, 91, 3613-3618. [CrossRef]

39. Oberbach, T.; Begand, S.; Glien,W. In-vitro wear of different ceramic couplings. Key Eng. Mater. 2007, 330-332, 1231-1234. [CrossRef]

40. Oberbach, T.; Ortmann, C.; Begand, S.; Glien, W. Investigations of an alumina ceramic with zirconia gradient for the application as load bearing implant for joint prostheses. Key Eng. Mater 2009, 309-311, 1247-1250. [CrossRef]

41. Piconi, C.; Rimondini, L.; Cerroni, L. La Zirconia in Odontoiatria; Masson Elsevier: Milano, Italy, 2008.

42. Nawa, M.; Nakamoto, S.; Sekino, T.; Niihara, K. Tough and strong Ce-TZP/Alumina nanocomposites doped with titania. Ceram. Int. 1998, 24, 497-506. [CrossRef] 
43. Ban, S.; Sato, H.; Suehiro, Y.; Nakanishi, H.; Nawa, M. Biaxial Flexure Strength and Low Temperature Degradation of CeTZP/Al2O3 Nanocompsite and Y-TZP as Dental Restoratives. J. Biomed. Mater. Res. Appl. Biomater. 2008, 87, 492-498. [CrossRef] [PubMed]

44. Oshima, Y.; Iwasa, F.; Tachi, K.; Baba, K. Effect of Nanofeatured Topography on Ceria-Stabilized Zirconia/Alumina Nanocomposite on Osteogenesis and Osseointegration. Int. J. Oral Maxillofac. Implant. 2017, 32, 81-91. [CrossRef]

45. Rieger, W.; Leyen, S.; Weber, W. The use of bioceramics in dental and medical applications. Digit. Dent. News 2009, 3, 6-13.

46. Spies, B.C.; Balmer, M.; Patzelt, S.B.M.; Vach, K.; Kohal, R.J. Clinical and patient-reported outcomes of a zirconia oral implant: Three-year results of a prospective cohort investigation. J. Dent. Res. 2015, 94, 1385-1391. [CrossRef]

47. Palmero, P.; Fornabaio, M.; Montanaro, L.; Reveron, H.; Esnouf, C.; Chevalier, J. Towards long lasting zirconia-based composites for dental implants. Part I: Innovative synthesis, microstructural characterization and in vitro stability. Biomaterials 2015, 50, 38-46. [CrossRef]

48. Burkhardt, F.; Harlass, M.; Adolfsson, E.; Vach, K.; Spies, B.; Kohal, R.-J. A Novel Zirconia-Based Composite Presents an Aging Resistant Material for Narrow-Diameter Ceramic Implants. Materials 2021, 14, 2151. [CrossRef]

49. Apel, E.; Ritzberger, C.; Courtois, N.; Reveron, H.; Chevalier, J.; Schweiger, M.; Rothbrust, F.; Rheinberger, V.M.; Höland, W. Introduction to a tough, strong and stable Ce-TZP/MgAl2O4 composite for biomedical applications. J. Eur. Ceram. Soc. 2012, 32, 2697-2703. [CrossRef]

50. Fornabaio, M.; Reveron, H.; Adolfsson, E.; Montanaro, L.; Chevalier, J.; Palmero, P. Design and development of dental ceramics: Ecxamples of current innovations and future concepts. In Advances in Ceramic Biomaterials; Palmero, P., Cambier, F., De Barra, E., Eds.; Woodhead: Duxford, UK, 2017; pp. 355-390.

51. Reveron, H.; Fornabaio, M.; Palmero, P.; Fürderer, T.; Adolfsson, E.; Lughi, V.; Bonifacio, A.; Sergo, V.; Montanaro, L.; Chevalier, J. Towards long lasting zirconia-based composites for dental implants: Transformation induced plasticity and its consequence on ceramic reliability. Acta. Biomater. 2017, 48, 423-432. [CrossRef] [PubMed]

52. Altmann, B.; Karygianni, L.; Al-Ahmad, A.; Butz, F.; Bächle, M.; Adolfsson, E.; Fürderer, T.; Courtois, N.; Palmero, P.; Follo, M.; et al. Assessment of novel long-lasting ceria-stabilized zirconia-based ceramics with different surface topographies as implant materials. Adv. Funct. Mater. 2017, 27, 1702512. [CrossRef]

53. Miura, M.; Hongoh, H.; Yogo, T.; Hirano, S. Formation of plate-like lanthanum- $\beta$-aluminate crystal in Ce-TZP matrix. J. Mater. Sci. 1994, 29, 262-268. [CrossRef]

54. Burger, W.; Kiefer, G. Ceramic composites for tailored material properties. J. Compos. Sci. 2021, submitted.

55. Gottwik, L.; Wippermann, A.; Kuntz, M.; Denkena, B. Effect of strontium hexaluminate on the damage tolerance of yttria-stabilized zirconia. Ceram. Intl. 2017, 43, 15891-15898. [CrossRef]

56. Denkena, B.; Wippermann, A.; Busemann, S.; Kuntz, M.; Gottwik, L. Comparison of residual strength behavior after indentation, scratching and grinding of zirconia-based ceramics for medical-technical applications. J. Eur. Ceram. Soc. 2018, 38, 1760-1768. [CrossRef]

57. Bethke, A.; Pieralli, S.; Kohal, R.-J.; Burkhardt, F.; Von Stein-Lausnitz, M.; Vach, K.; Spies, B.C. Fracture Resistance of Zirconia Oral Implants In Vitro: A Systematic Review and Meta-Analysis. Materials 2020, 13, 562. [CrossRef] [PubMed]

58. Duntu, S.H.; Tetteh, F.; Ahmad, I.; Islam, M.; Boakye-Yiadom, S. Characterization of the structure and properties of processed alumina-graphene and alumina-zirconia composites. Ceram. Int. 2021, 47, 367-380. [CrossRef]

59. Manshor, H.; Aris, S.M.; Azhar, A.Z.A.; Abdullah, E.C.; Ahmad, Z.A. Effect of Titania $\left(\mathrm{TiO}_{2}\right)$ Addition to Zirconia Toughened Alumina (ZTA) Phases, Hardness and Microstructure. Adv. Mater. Res. 2015, 1087, 293-298. [CrossRef]

60. Wahsh, M.M.S.; Khattab, R.M.; Zawrah, M.F. Sintering and technological properties of alumina/zirconia $/ \mathrm{nano}^{-T i O} 2 \mathrm{ceramic}$ composites. Mater. Res. Bull. 2013, 48, 1411-1414. [CrossRef]

61. Khaskhoussi, A.; Calabrese, L.; Currò, M.; Ientile, R.; Bouaziz, J.; Proverbio, E. Effect of the Compositions on the Biocompatibility of New Alumina-Zirconia-Titania Dental Ceramic Composites. Materials 2020, 13, 1374. [CrossRef] [PubMed] 